Discussion Paper No. 11-033

\title{
Human Capital Investment Strategies in Europe
}

Friedhelm Pfeiffer and Karsten Reuß

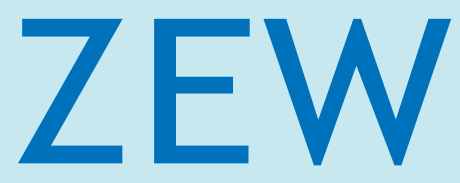

Zentrum für Europäische Wirtschaftsforschung $\mathrm{GmbH}$

Centre for European

Economic Research 
Discussion Paper No. 11-033

\title{
Human Capital Investment Strategies in Europe
}

\author{
Friedhelm Pfeiffer and Karsten Reuß
}

Download this ZEW Discussion Paper from our ftp server:

ftp://ftp.zew.de/pub/zew-docs/dp/dp11033.pdf

Die Discussion Papers dienen einer möglichst schnellen Verbreitung von neueren Forschungsarbeiten des ZEW. Die Beiträge liegen in alleiniger Verantwortung der Autoren und stellen nicht notwendigerweise die Meinung des ZEW dar.

Discussion Papers are intended to make results of ZEW research promptly available to other economists in order to encourage discussion and suggestions for revisions. The authors are solely responsible for the contents which do not necessarily represent the opinion of the ZEW. 


\section{Das Wichtigste in Kürze}

Die Erweiterung und Vertiefung der Europäischen Union schafft neue Möglichkeiten auch für die Bildungspolitik. Aufgrund der höheren Mobilität nimmt die Verschränkung von Bildungssystemen und regionalen Arbeitsmärkten zu. Die Bildungspolitik blickt damit neben den Bildungsinvestitionen und Ergebnisse innerhalb eines Landes zunehmend auf die Bildungsprozesse in Europa insgesamt. Dennoch gibt es bislang erst wenige Analysen zu optimalen Investitionsstrategien in die Humankapitalbildung in Europa, die den ganzen Lebenszyklus umfassen. Die vorliegende Studie möchte diese Forschungslücke schließen und zum Verständnis alternativer Investitionsstrategien und ihrer Konsequenzen für die Entwicklung des Humankapitals in Europa beitragen. Es werden die Wohlfahrtskonsequenzen von Strategien untersucht, die entweder auf unterschiedliche Altersgruppen, auf spezifische Bildungsgruppen oder Länder fokussieren.

Als theoretische Grundlage dient ein Modell der Humankapitalbildung, das durch abnehmende Grenzerträge von Bildungsinvestitionen in einer Periode gekennzeichnet ist, und das dem kumulativen und synergetischen Prozess der Bildung von Fähigkeiten im Lebenszyklus Rechnung trägt. Die Parameter, die den Aufbau des Humankapitals sowie die Entwicklung der individuellen Einkommen im Lebenszyklus und deren Verteilung steuern, werden für 29 Länder Europas mit Hilfe der PISA Daten sowie offiziell verfügbarer Statistiken zur Bevölkerung, Altersverteilung, Bildungsausgaben, Lebensdauer und Pro-Kopf Einkommen ermittelt. Humankapitalentwicklung, Einkommen und Lebenserwartung hängen maßgeblich von den Humankapitalinvestitionen in der Kindheit ab, die aus dem familiären und schulischen Umfeld resultieren. Im Erwachsenenalter entscheiden die Individuen über die optimale Höhe ihrer Bildungsinvestitionen.

Die Ergebnisse der unterschiedlichen Bildungsinvestitionsstrategien werden mit einer Wohlfahrtsfunktion bewertet, in der neben dem Ziel der Effizienz das Ziel der Gleichheit unterschiedlich gewichtet werden kann. Beispielsweise hat in skandinavischen im Vergleich zu angelsächsischen Ländern das Ziel der Gleichheit ein höheres Gewicht. Die Bewertung bezieht jeweils die Humankapitalbildung im gesamten Lebenszyklus ein, und nicht nur die Ergebnisse von spezifischen Bildungsstufen, wie etwa der Hochschul- oder Vorschulbildung.

Als Ergebnis zeigt sich unter anderem, dass mehr Bildungsinvestitionen in die Förderung benachteiligter Kinder bereits in der Vorschulzeit getätigt werden sollten, wenn das Gleichheitsziel im Vordergrund steht. Auch wenn das Effizienzziel Priorität hat, verbessern zusätzliche Investitionen in der frühen Lebensphase für alle Kinder die gesellschaftliche Wohlfahrt. Falls sowohl die Kosten der Ausbildung wie auch die Bildungsertragsfunktion einheitlich in Europa sind, werden Politiken zur Verringerung der Ungleichheit von Bildungsinvestitionen effektiver. 


\section{Nontechnical Summary}

Improving the education of youth is one of the most prominent policy goals in Europe. While most economists would agree with the aim, the optimal timing and the optimal quantity of educational investments are in question.

This paper analyses alternative investment policies and their consequences for the evolution of human capital in Europe based on a model of age dependent skill formation where the life span depends on investments during childhood. A model is calibrated for a population living in 29 European countries in the year 2006. In the study Europe is either the sum of these individual countries or it is a hypothetical entity constructed from the 29 European countries.

What makes the approach special is the analysis of the returns to education of alternative educational policies targeted at certain countries, ages or productivity levels for two counterfactual policy regimes, one regime assuming a single labour market and the other presupposing the actual state of diversity. In the model, investments for young individuals under the age of eighteen years are traced back to the family and teaching environment. In adulthood individuals optimize the amount of educational investments, given the overall amount of investments in the society. We analyse the consequences of each investment policy for human capital formation over the whole life cycle and do not focus on specific developmental stages like preschool or tertiary education.

The results demonstrate that optimal investment strategies, whether they are oriented towards age, regions or skill levels, crucially depend on the weights a society puts on equality. If equality is important enough more investment in Europe are needed for disadvantaged children during childhood. If the aim of equality is less important, additional investments need to be directed more generally to people of younger ages. Furthermore, it turns out that high levels of income inequality and a high skill level increases the optimal amount of investments, especially during younger adulthood. In the case where educational costs and skill premia are modelled as homogeneous in Europa the effectiveness of policies to reduce inequality would be higher.

The findings result from the idea of age depended skill formation with decreasing learning multiplier over time and decreasing marginal returns to investment in the skill production function. Further research is needed first for empirically assessing the skill multiplier from childhood in the different European countries with improved data. Second, additional research is needed to investigate the welfare consequences of public and private investment processes and alternative assumptions about their interdependencies. 


\title{
Human capital investment strategies in Europe
}

\author{
Friedhelm Pfeiffer** and Karsten Reuß* \\ *ZEW Mannheim \\ ** ZEW Mannheim, University of Mannheim
}

May $10^{\text {th }}, 2011$, comments welcome

\begin{abstract}
:
The paper analyses alternative investment policies and their consequences for the evolution of human capital in Europe based on a model of age dependent skill formation where the life span depends on investments during childhood. What makes the approach special is the analysis of the returns to education of alternative educational policies targeted at certain ages, countries, or productivity levels for two counterfactual policy regimes, one regime assuming the actual state of diversity and the other a unified Europe. Our results indicate that investments need to be directed more generally to people of younger ages in Europe. If equality is important enough additional investment should specifically be directed to disadvantaged individuals during childhood. Furthermore, high levels of life cycle income inequality and a high skill level increase the optimal amount of investments during younger adulthood. In a unified Europe, the effectiveness of policies to reduce inequality would be higher.
\end{abstract}

\section{Keywords:}

Human capital investment, life cycle skill formation, welfare function, Europe.

JEL-classification: D87, I12, I21, J13

\section{Acknowledgements:}

We gratefully acknowledge support from the Leibniz Association, Bonn, through the grant "Noncognitive Skills: Acquisition and Economic Consequences". We thank Dominik Wellhäuser for careful reading and many valuable comments.

\section{Addresses:}

Friedhelm Pfeiffer, Centre for European Economic Research (ZEW), P.O. Box 103443, D-68034 Mannheim. Tel.: +49-621-1235-150, E-mail: pfeiffer@zew.de.

Karsten Reuß, Centre for European Economic Research (ZEW), P.O. Box 103443, D-68034 Mannheim. Tel.: +49-621-1235-287, E-mail: reuss@ zew.de. 


\section{Introduction}

Economists study the formation of human capital over the life cycle and its welfare consequences. Teaching is regarded as the major channel for fostering skills and human capital. According to political rhetoric educational policies overcome market failure in reaching the optimal amount of investment and in addition equalize educational opportunities. The European Commission (2010), for instance, postulates that improving the education of youth is one of the most prominent policy goals in Europe.

While most economists would agree with the aim, the optimal timing and the optimal quantity of educational investments are in question. Since deep-seated skills are created early in the human developmental process (Amor 2003, Blomeyer et al. 2009, 2010, Heckhausen and Heckhausen 2008, Heckman 2007, among others) the priorities in public educational spending are under scrutiny. The formation of cognitive skills, such as intelligence, memory power and reasoning, and selfregulatory skills, such as motivation, delay of gratification and persistence, begins in early childhood, influenced by parent-child interaction. The level of these skills is decisive for becoming a productive member of society and for economic performance as well (see Cunha and Heckman 2007, 2009, Hanushek and Wössmann 2008, among others).

There exists a bunch of public educational programmes covering preschool, primary and secondary education in all European countries. Furthermore, governments in modern European societies are engaged in post-secondary education as well as training and try to promote lifelong learning (OECD 2010, among others). While each of these educational programmes receives a great deal of attention in research ${ }^{1}$, a comprehensive empirical assessment of the patterns of investment into human capital during the life-cycle and its welfare implications under different educational regimes in Europe is still not available ${ }^{2}$, mainly for three reasons.

First, counterfactual evidence of alternative human capital investments over the life cycle is scarce due to a lack of longitudinal studies ranging from the cradle to the grave (see Cunha et al. 2006, among others). Second, policies aiming at fostering human capital during childhood will reach part of their expected economic impacts only in the following twenty to forty years (see Pfeiffer and Reuß 2008, among others). This period is beyond political foresight and children, as a rule have no voting power. Third, European countries are responsible for educational and labour

\footnotetext{
${ }^{1}$ For instance, policy reforms in secondary or postsecondary education have been studied by Bergh and Fink (2009), Hunter et al. (2009), Johnson and Turner (2009), Lerner et al. (2008) and Wössmann (2008), among others.

${ }^{2}$ Heckman and Jacobs (2009) investigate human capital formation from the viewpoint of skill bias and greater turbulence in labour markets in Europe. Pfeiffer and Reuß (2008) examine returns to education when skill formation is age dependent. Their empirical part focuses on Germany.
} 
market policies. These policies differ widely in Europe (see Borgloh et al. 2011, among others) and coordination will take time.

Our contribution to the burgeoning literature on life-span human capital formation is threefold. We examine welfare implications of alternative educational policies to foster human capital based on a version of our model of life cycle skill formation (Pfeiffer and Reuß 2008). We extend this model with respect to several aspects. Life span now depends on the stream of investments in childhood as is suggested by research from Friters et al. (2010), among others. Parameters that determined income inequality and economic productivity can now be independently varied in the human capital production function. A welfare function assesses the alternative educational policies with different weights put on equality. For instance equality is more important in Scandinavian countries, compared to countries within Europe. The model is calibrated for a population living in 29 European countries in the year 2006.

Another innovative feature of our analysis is the examination of welfare implications of various educational policies for a counterfactual policy regime. One policy regime represents the actual status of labour market diversity the other assumes the hypothetical state of a single labour market in Europe. We analyse alternative educational investment strategies aligned to specific regions, ages and productivity levels for each of these two policy regimes.

The study demonstrates that additional investment should be shifted to the young population with low investments and low productivity if equality within the society is important in the welfare function. If the aim of equality is less important, additional investments need to be directed more generally to people of younger ages. The welfare effects of educational investments are higher in a single labour market if equality is more important.

The paper is structured as follows. Section two introduces the relevant data and the considered European countries. Section three discusses the model of skill and human capital formation and section four the calibration of the functions with the data. Section five highlights the welfare implications of alternative educational investment strategies. Section six concludes.

\section{Data sources and descriptive findings}

In what follows Europe consists either of the following 29 countries: Austria, Belgium, Bulgaria, Croatia, Czech Republic, Denmark, Estonia, Finland, France, Germany, Greece, Hungary, Iceland, Ireland, Italy, Latvia, Lithuania, Luxembourg, Netherlands, Norway, Poland, Portugal, Romania, Slovak Republic, Slovenia, Spain, Sweden, Switzerland and United Kingdom. Alternatively, Europe is a hypothetical 
entity constructed from these 29 European countries. Since currently there is no political entity for these 29 countries and aggregate official statistics are not available, these have been created from different sources. The 29 European countries have been selected such that data on educational outcomes and investment costs, demographics, GDP and the inequality of income are available. ${ }^{34}$

Table 1 displays the population size, age structure (below 18, above 65 years old), educational expenditures as well as the GDP and income inequality for the hypothetical Europe as well as the mean, minimum and maximum values for the 29 individual countries. The countries differ significantly in many of the examined characteristics. For instance, the number of inhabitants varies between 300000 in Iceland and 82.4 million in Germany. Overall 508.7 million people live in Europe. In most European countries the middle-aged group is the largest one. The fraction of inhabitants below the age of 18 varies between 16.1\% (Italy) and 24.9\% (Iceland). In Scandinavian countries and France the fraction is above 20\%, whereas in Germany and Spain, among others, it is less than 17\%. This divergent age patterns have implications for educational policies.

Table 1: Population size, age distribution, educational expenditures, GPD/capita and income inequality for Europe and the 29 European countries

\begin{tabular}{lcccccc}
\hline \hline Population & $\begin{array}{l}\text { fraction } \\
\text { below 18 }\end{array}$ & $\begin{array}{l}\text { fraction } \\
\text { above 65 }\end{array}$ & $\begin{array}{l}\text { Public } \\
\text { educational } \\
\text { expenditures }\end{array}$ & $\begin{array}{l}\text { GDP/ } \\
\text { capita }\end{array}$ & $\begin{array}{l}\text { Quintile } \\
\text { Income } \\
\text { Ratio }\end{array}$ \\
\hline Europe & 508678000 & $18.5 \%$ & $17.6 \%$ & $5631 €$ & $22329 €$ & 6.05 \\
\hline Mean $^{\text {a) }}$ & 17540620 & $19.0 \%$ & $16.6 \%$ & $5769 €$ & $23168 €$ & 4.67 \\
Min. $^{\text {a) }}$ & 299891 & $16.1 \%$ & $11.9 \%$ & $1453 €$ & $8307 €$ & 3.40 \\
Max. $^{\text {a) }}$ & 82437995 & $24.9 \%$ & $20.8 \%$ & $12168 €$ & $62268 €$ & 7.90 \\
\hline \hline
\end{tabular}

Source: OECD.stat (2009), own calculations, see text. ${ }^{\text {a) }}$ These row shows the respective mean, standard deviation, minimum and maximum values from the 29 countries. ${ }^{\text {b) }}$ Euro, real values 2006.

GDP per capita varies from $8307 €$ (Croatia) to $62268 €$ in Luxembourg, showing significant disparities in Europe. European countries have around 18 million inhabitants on average and the hypothetical European has an average GDP per capita of $22329 €$. Inequality is measured with the ratio of overall income of the 20 percent of population with the highest income (highest quintile) to the overall

\footnotetext{
${ }^{3}$ GDP per capita is calculated for Euro 2006 values using PPP from OECD.stat (2009). The overall population sizes, the age structure and measures of income inequality have been taken from Eurostat (2010).

${ }^{4}$ Turkey has not been included, although data are available. Turkey has been excluded from the study, because most of the territory of Turkey belongs to Asia. Since Turkey has a comparatively young and large population, the inclusion of Turkey would have made a difference.
} 
income of the 20 percent of the population with the lowest income (lowest quintile), taken from Eurostat (2009). Income inequality varies from 3.4 (Denmark) to 7.9 (Latvia). In the hypothetical Europe inequality is as high as 6, much higher than the simple average of the inequality measurers suggest. Therefore, inequality in the hypothetical Europe is higher, for instance, than in the US. With respect to average GDP per capita and inequality the hypothetical Europe is more similar to Greece than to France, Germany or Sweden, for instance.

These observations would have implications if a unification of educational policy took place. For instance, educational expenditures presumably would change in case of a majority rule. Currently annual public educational expenditures (taken from OECD 2010) differ widely, between $1453 €$ per student in Romania and Denmark, Norway or Luxembourg where expenditures exceed $10000 €$ per student.

The measure of educational performance has been taken from PISA scores 2006 (OECD 2006) averaged for math, science and reading and in each of the 29 countries. Table 2 compares the resulting average PISA scores for Europe and summarizes the mean, and the minimum and maximum values for the 29 European countries.

Table 2: The distribution of PISA scores for Europe and the sample of 29 European countries

\begin{tabular}{cccccccc}
\hline \hline Percentile & 5 & 10 & 25 & $\mathbf{5 0}$ & 75 & 90 & 95 \\
\hline Europe & 332.7 & 367.4 & 426.7 & $\mathbf{4 9 0 . 7}$ & 557.9 & 607.5 & 634.9 \\
\hline Mean $^{\text {a) }}$ & 343.2 & 375.7 & 431.2 & $\mathbf{4 9 0 . 9}$ & 553.5 & 600.8 & 626.4 \\
Min. $^{\text {a) }}$ & 263.2 & 290.9 & 344.5 & $\mathbf{4 0 7 . 6}$ & 462.3 & 511.6 & 538.4 \\
Max. $^{\text {a) }}$ & 425.5 & 454.6 & 504 & $\mathbf{5 5 6 . 5}$ & 606.6 & 645.9 & 669.9 \\
\hline \hline
\end{tabular}

Source: Own calculations, see text. ${ }^{\text {a) }}$ These rows show the respective mean, standard deviation, minimum and maximum values for 29 countries.

The inequality in educational performance in Europe is higher than the country specific inequality. On average educational performance is high in Finland (556.5) and the Netherlands (521) and low in Romania (407.6) and Bulgaria (417). As a rule, the inequality of educational performance is inversely related to the average PISA score. For instance, the 90-10 PISA ratio is 2 in Romania compared to 1.5 in Finland. There is a wide variety of educational expenditures per PISA score. For instance Norway investment is about $25 €$, while it is only $5 €$ in Croatia. 


\section{Skill and human capital formation over the life cycle}

The model of human capital formation consists of six equations, introduced in this section. Equation one and two govern skill development, equation three the formation of human capital formation from the age of zero to 18. Equation four governs the transformation of human capital into income, while equation five deals with the optimal investment into human capital from age 18 to 65. Equation 6 contains the welfare function of the society.

There are two skills and two equations for skill formation, one for cognitive skills, $S_{t}^{C}$, and one for non-cognitive or self-regulatory skills, $S_{t}^{N}$ (see equation 1,2). These two difference equations specify skill formation and depreciation on an annual basis over the life span with individual $n$, living in country $j$. It is assumed that returns to education depend on age. Investment later in life is not able to enhance the skill level as much as in early childhood, even though the higher skill level may complement investment. In order to reflect age-dependent processes, two learning multipliers are added determining the person's learning aptitude, one for cognitive, $1_{t}^{\mathrm{C}}$, and one for self-regulatory skills, $\mathrm{l}_{\mathrm{t}}^{\mathrm{N}}$, respectively (introduced in Pfeiffer and Reuß 2008). The learning multipliers depend on age in a way that is regarded to be consistent with neurobiological and psychological findings from the child development literature cited in the introduction (see Cunha and Heckman 2007, and Heckman 2007, among others).

$$
\left.S_{t, n, j}^{k}=l_{t}^{k} \cdot\left\{\frac{1}{3} \cdot S_{t-1, n, j}^{k}{ }^{\theta}+\frac{1}{3} \cdot S_{t-1, n, j}^{j}+\frac{1}{3} \cdot I_{t, n, j}^{k}\right\}^{\theta}\right\}^{\frac{1}{\theta}}+\left(1-\delta_{t-1}\right) \cdot S_{t-1, n, j}^{k}
$$

with $\delta_{t-1}=\frac{1}{a s \cdot(l e+1-t)}, k=C, N$ and $\mathrm{j}=C$ if $k=N, j=N$ if $k=C$ and $S_{t, i, j}^{k} \geq 0$.

The first term of equations $(1,2)$ represents skill formation with a CES production function. Next period skills are produced by both types of skills and investment. The parameter $\theta$ determines the degree of complementarity among skills and investment and can vary from 1 (complete substitutes) to $-\infty$ (complete complements). For $\theta=0$ the production function is of the Cobb Douglas type. The second part of equations $(1,2)$ introduces skill losses. Depreciation of skills is modest in childhood and accelerates with increasing age, assuming a life span of le years. The life span depends on the amount of investment (the family environment) during childhood. as is a parameter introduced to govern the dynamics of deprecation. If as is larger than 1, skill depreciation accelerates towards the end of the life span. In the last period, the individual loses all skills (and dies). For the analyses a value as $=5.85$ is used. In that case, equations $(1,2)$ imply self-productivity $\left(\partial S_{2}^{k} / \partial S_{1}^{k}>0\right.$; this is true for $\left.a s>1\right)$ and direct complementarity $\left(\partial^{2} S_{t}^{k} / \partial I_{t}^{k} \partial S_{t-1}^{j}>0\right)$ resulting from the CES production 
function as long as $\theta<1$ (Cunha and Heckman 2007). A detailed discussion of the production function is given in Pfeiffer and Reuss (2008).

In the following sections two variants of the model (scenario 1 and 2) are studied.

The formation of human capital in a given year is modelled as a function of cognitive and self-regulatory skills taking into account that human capital may accumulate or depreciate, for example, due to technological progress. Hence

$$
H_{t, n, j}=\psi_{A} \cdot \sqrt{S_{t, n, j}^{C} \cdot S_{t, n, j}^{N}}+\left(1-\delta_{t-1}^{H}\right) \cdot H_{t-1, n, j},
$$

where $S_{\mathrm{t}}^{\mathrm{C}}$ and $\mathrm{S}_{\mathrm{t}}^{\mathrm{N}}$ are defined in equations $(1,2)$. Human capital depreciates according to $\delta_{t}^{H}=\theta_{H} \cdot \delta_{t}$, where $\theta_{H}$ is a parameter that may vary among individuals, jobs, industries or over time. A high value of $\theta_{H}$ induces an early human capital maximum (e.g., in sports); a small $\theta_{H}$, a later maximum (as, for example, in science). It is assumed that this basic structure explains human capital formation in all European countries.

However, the countries differ in their skill premium and their distribution of income relative to the skill heterogeneity due to differences in the functioning of labour market and considerations about equity, among others. In one country an individual with a certain human capital level will therefore earn less than he or she would earn in another country. Besides that in some countries human capital heterogeneity is small relative to the income heterogeneity, whereas in other countries it is rather large. In the model, individual income results from the individual human capital and the cumulated income of the country as follows:

$$
Y_{t, n, j}=\phi_{j} \cdot\left(1-I_{t, n, j}^{k^{*}}\right) \cdot \frac{\left(\frac{H_{t, n, j}}{\varnothing H_{j}}\right)^{\gamma_{j}}}{\sum_{n=1}^{N_{j}}\left(\frac{H_{t, n, j}}{\varnothing H_{j}}\right)^{\gamma_{j}}} \cdot \sum_{n=1}^{N_{j}} H_{t, n, j}
$$

with $N_{j}$ being the population of each country $j$. Two parameters are employed to model income patterns: $\phi_{j}$ reflects the transformation of human capital into income. E.g. if $\phi_{j}=1$, one unit of human capital in the country will earn one Euro. Hence the sum of human capital in a country will always be the same sum in Euros. For another example, if $\phi_{j}=2$, one unit of the human capital will earn two Euros.

Individual income depends on the parameter $\gamma_{j}$. The right hand side of equation (4) includes the ratio individual to average human capital. For the average individual $n$, the terms equal one for any $\gamma_{j}$. For individuals whose human capital differs from the 
mean, $\gamma_{j}$ will either lead to an income above or below the average resulting from the stock of human capital. If $\gamma_{j}=0$, all individuals in one country will earn the same amount of money irrespective of their particular skill levels. If $\gamma_{j}=1$, individuals will earn exactly their level of human capital times $\phi_{j}$. As $\lim \gamma_{j} \rightarrow \infty$, the person with the highest level of human capital will earn all the income generated in a country.

Until the age of 18 , the investments $I_{1 \ldots 1, i, j}^{k}$ are assumed to depend on family background and teaching. Investments are assumed to vary in such a way that it explains student performance. The calibration of the parameters is discussed in section 4. After the age of 18 years individuals are assumed to choose the amount of investment that maximises their expected lifetime income. They can either invest $I_{t, n, j}^{k^{*}}$ units into their skills (see equation 5) or earn an income at the labour market with the available level of human capital. If the available time is invested in education, no income can be earned. Individuals are assumed to maximize the following function (5):

$$
I_{t, n, j}^{k^{*}}=\arg \max \left(\sum_{t=18}^{65} \frac{Y_{t, n, j}\left(I_{t-1, t-2, \ldots,}^{C^{*}}, I_{t-1, t-2, \ldots}^{N^{*}}\right)-\left(I_{t, n, j}^{C^{*}}+I_{t, n, j}^{N^{*}}\right) * 0.5 * C_{j}}{(1+r)^{t-18}}\right),
$$

where $r=0.02$ denotes a discount factor of 2 per cent and parameter $C_{j}$ represents the cost of one unit of education for country $j$. After the age of 65 all investments will be zero because income cannot be earned anymore after that age. As the number of people living in each country $\left(N_{j}\right)$ is large and the individual impact is only marginal, it is assumed that individuals cannot influence the average human capital level of their country $\left(\varnothing H_{j}\right)$ or the sum of human capital in their country $\left(\sum_{n=1}^{N_{j}} H_{t, n, j}\right)$. Under that assumption equation (5) is solved and the individual amount of investment has been calculated.

To assess alternative educational policies, the following welfare function is used for our population (Sen et al. 1997):

$W(Y)=\left(1-A_{\varepsilon}(Y)\right) \cdot \sum_{i=1}^{N} y_{n}$, with

$$
A_{\varepsilon}(Y)=1-\left[\frac{1}{\sum_{j=1}^{J} N_{j}} \sum_{n=1}^{N}\left(\frac{y_{n}}{\mu}\right)^{1-\varepsilon}\right]^{\frac{1}{1-\varepsilon}} .
$$


$A_{\varepsilon}$ denotes the Atkinson index (Atkinson 1970), which illustrates the trade-off between efficiency and equality in educational policy. The index is a discrete measure of inequality for an income distribution of a population with $N$ European citizens. The equation $y_{i}=\sum_{t=18}^{65} r_{t} \cdot Y_{t}$ represents the discounted individual income accumulated over the working life, factor $\mu$ denotes the average human capital of the population and $\varepsilon$ is a parameter for different degrees of equity preferences in the society. Assuming $\varepsilon=0$, a society does not care about equity at all. For $\varepsilon=\infty$, the index depends only on the welfare of the poorest individual within the society. The Atkinson Index is normalized between 0 and 1. If $A_{\varepsilon}(Y)=0$, no inequality is measured in the distribution, while inequality is at its maximum if $A_{\varepsilon}(Y)=1$.

The society is assumed to maximize function (6) for the life-cycle welfare of the European population. Educational policies are restricted by scarcity exogenously. In the case of $\varepsilon=0$ the society will only maximize the sum of income without considering inequality. On the other hand, if $\lim \varepsilon \rightarrow \infty$, only the income of the poorest person in the society is relevant for governing educational policies. In social reality equity considerations may vary between $0.5 \leq \varepsilon \leq 1.5$ (Atkinson 1970).

\section{Calibration of model parameters}

To investigate educational policies in Europe, several model parameters have to be calibrated with existing data. In order to test the sensitivity of the analysis and to take policy regimes properly into account, some parameters have been calibrated for two different cases. In the first one, Europe consists of heterogeneous labour markets and educational costs, in the second one, a homogeneous labour market and homogenous educational costs are presumed. In a first step, the PISA-scores for all individuals $i$ younger than 18 years in each country $j$ have been obtained by a cubic spline interpolation (De Boor 1978). The PISA-score at age $15\left(P_{15}\right)$ is assumed to result from cognitive and self-regulatory skills:

$\mathrm{P}_{15, \mathrm{i}, \mathrm{j}}=\psi_{\mathrm{P}} \cdot \sqrt{S_{15, \mathrm{i}, \mathrm{j}}^{\mathrm{C}} \cdot \mathrm{S}_{15, \mathrm{i}, \mathrm{j}}^{\mathrm{N}}} \cdot$

Equation (7) explains the potential performance of an individual in performing a task as a function of her cognitive and self-regulatory skills at the age of 15 years. Both skills are necessary to complete the task successfully and may interact in complex ways. A person with a high (low) level of cognitive skills could produce low (high) results if her motivation is low (high). Performance is modelled by means of a Cobb Douglas function with equal weights for cognitive and self-regulatory skills, since the literature provides evidence for both skills to be equally important (Duckworth and Seligman 2005, Heckman 2007, among others). The factor $\psi_{A}$ is an adjustment factor for different normalizations of performance scores and their respective distributions. The model is calibrated to reach the PISA 2006 test score 
distributions for 29 European countries for a population of 100,000 representative young Europeans.

Investment levels $I_{0 . .18, i, j}^{k}$ are calculated in a way that in each country the PISA distribution is generated by equation (7). Table 3 shows resulting values for $\theta=0^{5}$. They differ from 0.16 to 2.06 demonstrating the inequality of investments which stems from the inequalities in the family and teaching environment.

After period 18 investments are assumed to result from equation (5) and the heterogeneity of income for the same amount of skills from heterogeneous national labour markets. Based on the investments in young age, the parameter $\phi_{j}$ is calibrated such that all working individuals between the age of 18 and 65 years annually produce the GDP of the country (the sum of incomes in each country is equal to the total GDP). The GDP per capita results from the division of a country's GDP by the number of inhabitants. The parameter $\gamma_{j}$ is calibrated to match the observed income inequality in Europe (see table 1).

Table 3: Simulated educational investments $I_{0 . \ldots 18, i, j}^{k}$ across the percentiles

\begin{tabular}{cccccccc}
\hline Percentile & 5 & 10 & 25 & $\mathbf{5 0}$ & 75 & 90 & 95 \\
& \multicolumn{7}{c}{$\theta=0$} \\
\hline Europe & 0.16 & 0.27 & 0.51 & $\mathbf{1}$ & 1.37 & 1.8 & 2.06 \\
mean & 0.2 & 0.3 & 0.54 & $\mathbf{0 . 9 8}$ & 1.33 & 1.73 & 1.97 \\
Std & 0.09 & 0.11 & 0.15 & $\mathbf{0 . 1 8}$ & 0.24 & 0.25 & 0.25 \\
Min & 0.03 & 0.07 & 0.19 & $\mathbf{0 . 5}$ & 0.71 & 1.03 & 1.22 \\
Max & 0.51 & 0.67 & 0.97 & $\mathbf{1 . 3 9}$ & 1.79 & 2.17 & 2.41 \\
\hline \hline
\end{tabular}

Table 4 displays the calibrated parameters ${ }^{6} . \phi_{j}$ indicate how much larger income in a country is compared to its human capital, $\gamma_{j}$ shows how much larger income inequality is compared to human capital inequality. The factor $\phi_{j}$ is large in high income countries like Luxembourg (9.77), Norway and Ireland, which have average levels of investments ( $\varnothing I_{0 . .18}$ being close to 1$)$. The value for $\phi_{j}$ is low in Poland (1.33), Croatia and Romania.

Croatia's human capital is only slightly below the average but the GDP per capita is much lower. Romania, on the other hand, has a low level of human capital leading to a low income. $\gamma_{j}$ is high in countries with low human capital inequalities and high

\footnotetext{
${ }^{5}$ For a more detailed compare Pfeiffer and Reuß (2008).

${ }^{6}$ Note that values do not vary much between simulations for different values of $\theta$. Hence, only the standard case $\theta=0$ is documented in Table 4.
} 
income inequality, which holds in particular for the Baltic countries (e.g., Latvia has the maximum value of 3.63). $\gamma_{j}$ is small in countries with high human capital inequalities and low income inequality, for instance in Bulgaria $\left(\gamma_{j}=1.42\right)$.

Table 4: Calibrated values of labour market parameters for heterogeneous European countries

\begin{tabular}{lcc}
\hline \hline Country & $\phi_{j}$ & $\gamma_{j}$ \\
\hline Europe & 3.51 & 2.71 \\
\hline mean & 3.49 & 2.41 \\
min & 1.33 & 1.42 \\
$\max$ & 9.77 & 3.63 \\
\hline \hline
\end{tabular}

If a single European labour market is assumed, there is only one $\phi$ and one $\gamma$ for all countries. The European GDP per capita is $22,367.43 €$ and the European Quintile Ratio is 6. This results in $\phi=3.51$ and $\gamma=2.71$. The average value of $\gamma$ is relatively high for a homogenous labour market in Europe compared to the average value in the case of a heterogeneous labour market $\left(\gamma_{j}=2.41\right)$. Thus, if Europe is assumed to have a homogenous labour market, higher inequality may result.

Life span depends on investments. The underlying empirical relationship results from the following regression for the 29 countries:

$\log (l e)=\beta_{0}+\beta_{1} \cdot \log ($ GDP $/$ capita $)$

The total population size is used as a weight. The estimated value of $\beta_{1}$ is 0.07 and is significant at the $99 \%$ level, uncovering a strong relationship between educational investment (indicated by GDP per capita) and average life span in the sample of European countries. All combinations of income and life span that result from the estimation of parameter $\beta_{1}$ in equation (8) yield the function $l e(I)$ (see figure 1).

The relationship between investment and le in the model has an impact on two subsequent calibrations, although it is rather moderate. Life cycle skill formation is illustrated graphically in Figure 2.

The figure considers all countries and demonstrates their heterogeneity. In the upper left it shows cognitive skills for a population of 100,000 representative European individuals of one age cohort for $\theta=0$. All individuals are assumed to start with the same stock of cognitive skills, i.e. a value of 180 , but receive divergent investments 
until the age of 18 years $^{7}$. As can be seen in this figure, cognitive skills peak in the early 20 s and then decline continuously. The maximum values vary between more than 700 and less than 400 skill units in the population. Individuals with fewer educational investments and a lower skill level have a shorter life span.

Figure 1: Relationship between educational investments and life span

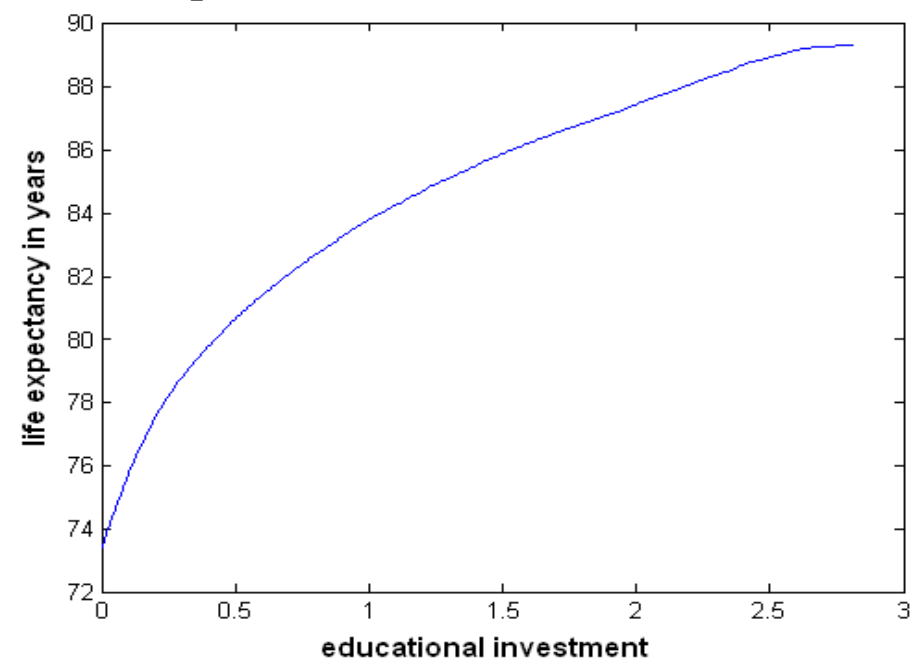

The beginning of the decline in cognitive skill depends on the life span. In the case of self-regulatory skills, all individuals start with the value of 180, too, but skills peak later, namely between the ages of 50 and 60 years. Because these skills are assumed to be more malleable throughout childhood (Cunha and Heckman 2007, Caspi et al. 2005), their heterogeneity resulting from parental investments varies between less than 300 and more than 1000 .

In the lower left part of figure 2, the development of human capital of a European population cohort is shown across its life span. For given human capital, the figure shows the incomes that an individual could receive if he or she worked full time between the ages of 18 and 65 years.

In contrast to skills, income does not only depend on parental investments during childhood, but also on conditions stemming from the labour market and the general productivity in a country. In some countries such as Luxembourg and Norway, income is high relative to human capital, while in others, such as Poland and Romania it is low.

Human Capital is produced by both cognitive and self-regulatory skills and peaks between the ages of 40 and 57 years. As individuals with higher skills live longer, they reach their maximum income later in life. In skill-intensive, high-income professions income peaks up to 17 years later than in low-income professions.

\footnotetext{
${ }^{7}$ For a discussion of different initial conditions see Pfeiffer and Reuß (2008).
} 
Figure 2: Cognitive and noncognitive skills, human capital and investments in adulthood
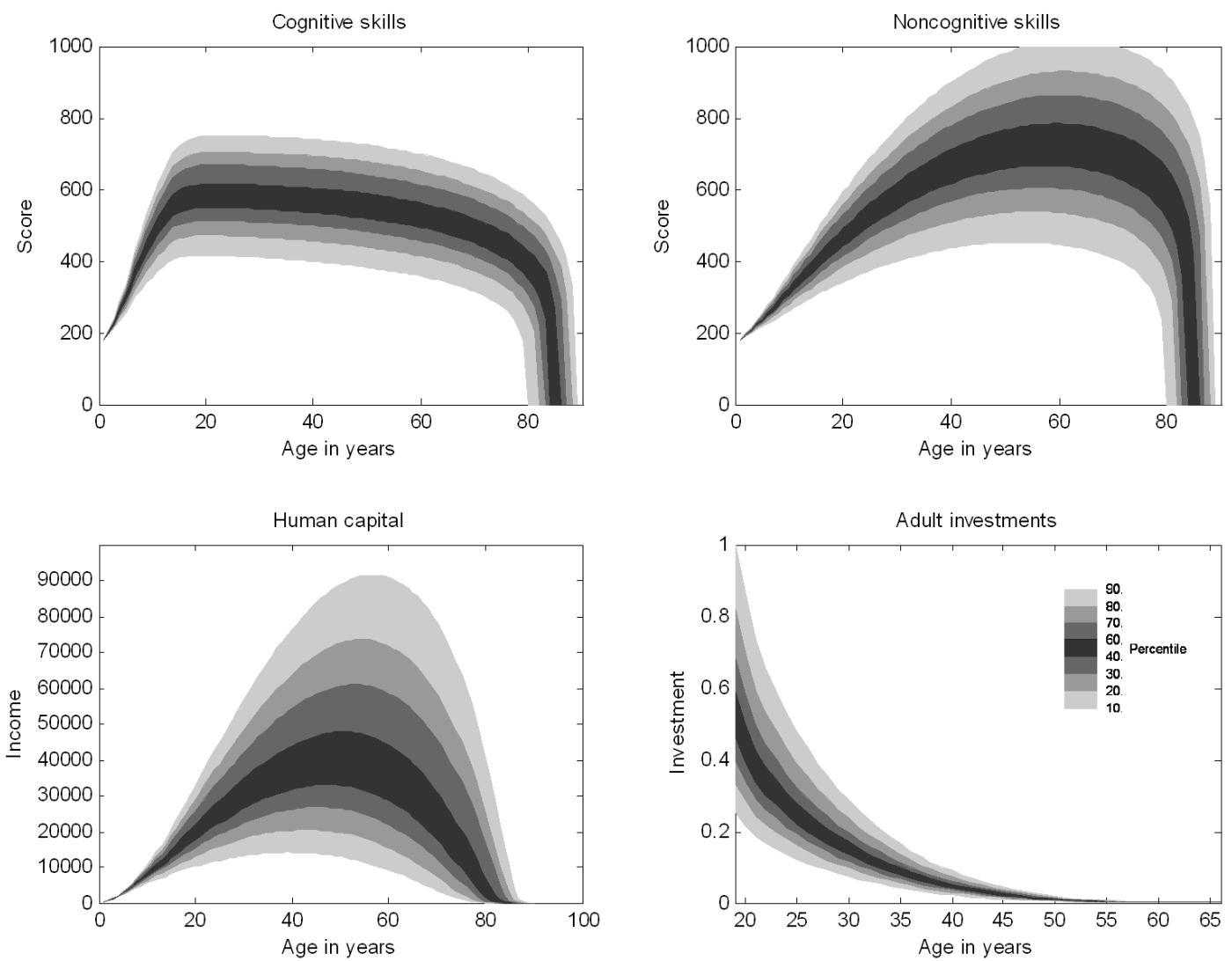

In the lower right part of figure 2 the amount of educational investments in adulthood that individuals choose to maximize their expected lifetime income is shown. Generally, individuals experience a trade-off: They have to decide to either start working or invest more in their education.

In early adulthood when returns to education are high, individuals tend to invest more in their education. The amount decreases with age and becomes negligible with the time. Individuals with higher human capital tend to invest more in education at young age, which is in line with the literature (see Pfeiffer and Reuß 2008, among others).

Individuals in countries with a high income inequality also tend to invest more in education. In Lativa for instance, where income quintile ratio is larger than 7, individuals invest on average 0.19 educational units per year between the ages of 18 and 65 . On the other hand, in countries with a quintile ratio smaller than 4 (e.g., Denmark and Switzerland) individuals only invest between 0.05 and 0.07 educational units. 


\section{Alternative Educational Policies}

\subsection{Alternative Policies and Regimes}

We study the welfare consequences of three alternative educational policies for two policy regimes in Europe.

Policy one aims at reducing country heterogeneity within Europe. According to this policy, each student who is younger than 18 years and comes from a country with PISA scores below the average PISA score receives the amount of investments that is needed to reach the European average of educational investments during their first 18 years of life. This amount is greater than zero for all European countries that invest less than the mean value of educational investments in Europe. The additional investments differ significantly between countries.

Policy two aims at increasing investments at certain ages while treating students of all European countries in the same way. In all countries, individuals under the age of 18 receive an additional education investment either in their preschool or their primary or secondary school. By our definition the preschool investment lasts from the age of 0 to 5 years, the primary investment from the age of 6 to 11 years and the secondary investment from the age of 12 to 17 years. The amount of investments is calculated in a way that balances total discounted costs with the expenditures of policy one.

Policy three provides educational investments either to the lower, medium or highest third of the PISA achievement distribution for the first 18 years of life. The investment is calculated in a way assuring that discounted costs resemble those of policy one.

The three policies are investigated for two policy regimes. In the first regime, European labour markets are assumed to be heterogeneous, hence, 29 different countries with distinct parameters $\phi_{j}$ and $\gamma_{j}$ are used in the model. Educational costs differ in each country. In the second regime, there is one homogeneous European labour market with one $\phi$ and one $\gamma$. In the second regime educational costs are assumed to be uniform across Europe. Obviously, these two regimes are idealized policy regimes. Reality presumably meets the conditions of a market structure which does not correspond completely to one of the suggested regimes.

\subsection{Heterogeneity in European Labour Markets}

Policy one aims at reaching the average level of educational investments in all countries. To make such an investment, $0.19 \%$ of the total annual European GDP (42.31 € per capita) has to be spent. For policy two, the investment amounts to $0.51 \%$ (preschool), $0.57 \%$ (primary) and $0.64 \%$ (secondary) of the total annual 
European GDP (113.00 € to $144.00 €$ per capita annually). These differences result from discounting educational spending. All in all, the discounted costs for policy two lasting for six years are equal to the costs of policy one lasting for 18 years. The annual spending of policy three is equal to the one for policy one. As investment costs differ, 0.12 educational units can be invested in the lower and middle third of the educational distribution, but only investments of 0.11 educational units can be financed for the upper third. Results for costs and returns are documented in Table 5.

Table 5: Costs and returns for alternative investment policies in policy regime one

\begin{tabular}{|c|c|c|c|c|c|}
\hline Policy & & $\begin{array}{l}\text { Duration } \\
\text { in years }\end{array}$ & Investments & $\begin{array}{c}\text { Annual average GDP } \\
\text { per capita increase }\end{array}$ & $\begin{array}{c}\text { Net income benefit per } \\
\text { student }\end{array}$ \\
\hline \multirow{4}{*}{$\begin{array}{l}\text { Policy } \\
\text { one, } \\
\text { region }\end{array}$} & Europe & 18 & 0.06 & $434 €$ & $16018 €$ \\
\hline & Mean & 18 & 0.06 & $452 €$ & $16302 €$ \\
\hline & Min & 18 & 0 & $0 €$ & $0 €$ \\
\hline & Max & 18 & 0.48 & $2489 €$ & $102725 €$ \\
\hline \multirow{4}{*}{$\begin{array}{l}\text { Policy } \\
\text { two, } \\
\text { preschool }\end{array}$} & Europe & 6 & 0.10 & $515 €$ & $19127 €$ \\
\hline & Mean & 6 & 0.10 & $521 €$ & $19269 €$ \\
\hline & Min & 6 & 0.10 & $199 €$ & $7799 €$ \\
\hline & Max & 6 & 0.10 & $1492 €$ & $61545 €$ \\
\hline \multirow{8}{*}{$\begin{array}{l}\text { Policy } \\
\text { two, } \\
\text { primary } \\
\text { school } \\
\text { Policy } \\
\text { two, } \\
\text { secondary } \\
\text { school }\end{array}$} & Europe & 6 & 0.12 & $389 €$ & $13119 €$ \\
\hline & Mean & 6 & 0.12 & $394 €$ & $13224 €$ \\
\hline & Min & 6 & 0.12 & $151 €$ & $5458 €$ \\
\hline & Max & 6 & 0.12 & $1138 €$ & $44055 €$ \\
\hline & Europe & 6 & 0.13 & $207 €$ & $4583 €$ \\
\hline & Mean & 6 & 0.13 & $209 €$ & $4587 €$ \\
\hline & Min & 6 & 0.13 & $81 €$ & $818 €$ \\
\hline & $\operatorname{Max}$ & 6 & 0.13 & $606 €$ & $18672 €$ \\
\hline \multirow{4}{*}{$\begin{array}{l}\text { Policy } \\
\text { three, } \\
\text { low- } \\
\text { skilled }\end{array}$} & Europe & 18 & 0.04 & $488 €$ & $18524 €$ \\
\hline & Mean & 18 & 0.04 & $482 €$ & $18263 €$ \\
\hline & Min & 18 & 0.01 & $116 €$ & $3639 €$ \\
\hline & Max & 18 & 0.08 & $1508 €$ & $62287 €$ \\
\hline \multirow{4}{*}{$\begin{array}{l}\text { Policy } \\
\text { three, } \\
\text { medium- } \\
\text { skilled }\end{array}$} & Europe & 18 & 0.04 & $312 €$ & $9942 €$ \\
\hline & Mean & 18 & 0.04 & $326 €$ & $10345 €$ \\
\hline & Min & 18 & 0.03 & $122 €$ & $4577 €$ \\
\hline & $\operatorname{Max}$ & 18 & 0.04 & $908 €$ & $33733 €$ \\
\hline \multirow{4}{*}{$\begin{array}{l}\text { Policy } \\
\text { three, } \\
\text { high- } \\
\text { skilled }\end{array}$} & Europe & 18 & 0.04 & $236 €$ & $6361 €$ \\
\hline & mean & 18 & 0.04 & $240 €$ & $6379 €$ \\
\hline & $\min$ & 18 & 0.01 & $22 €$ & $850 €$ \\
\hline & $\max$ & 18 & 0.07 & $596 €$ & $20536 €$ \\
\hline
\end{tabular}

The largest net income effect can be achieved with an additional preschool investment $(19,127 €$ per capita), followed by an investment in education for low- 
skilled students under 18 years $(18,524 €)$. Supporting low-skilled individuals instead of low-skilled countries leads to higher net benefits. In the long run, the largest net income effect (GDP per capita) is about $515 €$ annually if all cohorts benefit from the policy. Hence, spending $113 €$ per capita annually would result in an increase of $515 €$ if no crowding out of educational investments took place. The smallest returns stem from additional investments in secondary education.

Results for inequality are displayed in table 6 . The largest effect on the reduction of inequality is achieved if investments are directed to the low-skilled as intended by policy three (see table 6). If equality considerations become more important in the welfare function, supporting the low performing students is a welfare optimizing strategy.

Table 6: Changes in inequality for policy regime one

\begin{tabular}{lccc}
\hline \hline Policy & before policy & after policy & change \\
\hline Policy one, region & 6 & 5.31 & -0.69 \\
\hline Policy two, preschool & 6 & 5.53 & -0.47 \\
Policy two, primary school & 6 & 5.65 & -0.35 \\
Policy two, secondary school & 6 & 5.80 & -0.20 \\
\hline Policy three, low-skilled & 6 & 4.92 & -1.08 \\
Policy three, medium-skilled & 6 & 5.92 & -0.08 \\
Policy three, high-skilled & 6 & 6.30 & +0.30 \\
\hline \hline
\end{tabular}

Finally, table 7 summarizes the welfare changes depending on the degree of inequality aversion in a society. Societies with a zero inequality aversion $(\varepsilon=0)$ should shift more investments to younger children (policy two) while societies with a greater inequality aversion $(\varepsilon>0)$ should support mainly the low performing students (policy three, low-skilled). Policy one is dominated by either the first variant of policy two or the first variant of policy three. However, policy one is always better compared to the second and third variant of policy two and three.

Table 7: Welfare changes in policy regime one depending on inequality aversion $\varepsilon$

\begin{tabular}{lcccc}
\hline \hline & $\varepsilon=0$ & $\varepsilon=0.5$ & $\varepsilon=1$ & $\varepsilon=1.5$ \\
\hline Policy 1 & $1.45 \%$ & $1.92 \%$ & $4.38 \%$ & $10.82 \%$ \\
\hline Policy 2, preschool & $1.73 \%$ & $2.33 \%$ & $5.57 \%$ & $14.35 \%$ \\
Policy 2, primary & $1.19 \%$ & $1.61 \%$ & $3.83 \%$ & $9.77 \%$ \\
Policy 2, secondary & $0.41 \%$ & $0.60 \%$ & $1.54 \%$ & $4.00 \%$ \\
\hline Policy 3, low-skilled & $1.67 \%$ & $3.08 \%$ & $10.65 \%$ & $32.32 \%$ \\
Policy 3, medium-skilled & $0.90 \%$ & $0.89 \%$ & $0.54 \%$ & $-0.73 \%$ \\
Policy 3, high-skilled & $0.58 \%$ & $0.28 \%$ & $-0.94 \%$ & $-3.30 \%$ \\
\hline \hline
\end{tabular}




\subsection{Homogeneous Labour Market in Europe}

Although labour market policies are divergent in Europe, tendencies exist to unify these policies to a greater extent. The second policy regime therefore might become more realistic in the coming decades. One labour market is assumed to exist in Europe. Moreover educational costs are the same for all Europeans. The educational investments comply with those of the policies described for the heterogeneous Europe. Results of investments and net benefits are displayed in Table 8.

Table 8: Costs and returns for alternative investment policies in policy regime two

\begin{tabular}{|c|c|c|c|c|c|}
\hline Policy & & $\begin{array}{l}\text { Duration } \\
\text { in years }\end{array}$ & Investments & $\begin{array}{l}\text { Annual average } \\
\text { GDP per capita } \\
\text { increase }\end{array}$ & $\begin{array}{c}\text { Net income } \\
\text { benefit per } \\
\text { student }\end{array}$ \\
\hline \multirow[t]{4}{*}{ Policy one, region } & Europe 29 & 18 & 0.04 & $385 €$ & $13554 €$ \\
\hline & mean & 18 & 0.04 & $392 €$ & $13851 €$ \\
\hline & $\min$ & 18 & 0 & $0 €$ & $0 €$ \\
\hline & $\max$ & 18 & 0.42 & $4208 €$ & $148473 €$ \\
\hline \multirow{4}{*}{$\begin{array}{l}\text { Policy two, } \\
\text { preschool }\end{array}$} & Europe 29 & 6 & 0.10 & $523 €$ & $19521 €$ \\
\hline & mean & 6 & 0.10 & $521 €$ & $19390 €$ \\
\hline & $\min$ & 6 & 0.10 & $411 €$ & $14030 €$ \\
\hline & $\max$ & 6 & 0.10 & $715 €$ & $29136 €$ \\
\hline \multirow{4}{*}{$\begin{array}{l}\text { Policy two, primary } \\
\text { school }\end{array}$} & Europe 29 & 6 & 0.12 & $395 €$ & $13396 €$ \\
\hline & mean & 6 & 0.12 & $393 €$ & $13319 €$ \\
\hline & $\min$ & 6 & 0.12 & $311 €$ & $9389 €$ \\
\hline & $\max$ & 6 & 0.12 & $534 €$ & $20155 €$ \\
\hline \multirow{4}{*}{$\begin{array}{l}\text { Policy two, } \\
\text { secondary school }\end{array}$} & Europe 29 & 6 & 0.13 & $210 €$ & $4729 €$ \\
\hline & mean & 6 & 0.13 & $209 €$ & $4687 €$ \\
\hline & $\min$ & 6 & 0.13 & $160 €$ & $2506 €$ \\
\hline & $\max$ & 6 & 0.13 & $284 €$ & $8127 €$ \\
\hline \multirow{4}{*}{$\begin{array}{l}\text { Policy three, low- } \\
\text { skilled }\end{array}$} & Europe 29 & 18 & 0.04 & $482 €$ & $18221 €$ \\
\hline & mean & 18 & 0.04 & $470 €$ & $17761 €$ \\
\hline & $\min$ & 18 & 0.01 & $111 €$ & $3960 €$ \\
\hline & Max & 18 & 0.08 & $1107 €$ & $44075 €$ \\
\hline \multirow{4}{*}{$\begin{array}{l}\text { Policy three, } \\
\text { medium-skilled }\end{array}$} & Europe 29 & 18 & 0.04 & $314 €$ & $10043 €$ \\
\hline & mean & 18 & 0.04 & $322 €$ & $10307 €$ \\
\hline & $\min$ & 18 & 0.03 & $231 €$ & $7449 €$ \\
\hline & $\max$ & 18 & 0.04 & $386 €$ & $12309 €$ \\
\hline \multirow{4}{*}{$\begin{array}{l}\text { Policy three, high- } \\
\text { skilled }\end{array}$} & Europe 29 & 18 & 0.04 & $243 €$ & $6680 €$ \\
\hline & mean & 18 & 0.04 & $241 €$ & $6624 €$ \\
\hline & $\min$ & 18 & 0.01 & $44 €$ & $1295 €$ \\
\hline & $\max$ & 18 & 0.07 & $425 €$ & $11408 €$ \\
\hline
\end{tabular}


In case of a uniform Europe the educational investment intended by policy one can only be financed to an extent that leads to $93.5 \%$ of the average European investment due to the fact that education for countries with amounts below the average sum of investments becomes more expensive. For policy two, the investments amount to $0.51 \%$ (preschool), $0.57 \%$ (primary) and $0.64 \%$ (secondary) of the total annual European GDP and are equal to the results for the regime assuming a heterogeneous labour market within Europe. For policy three, the annual spending complies with the expenditures of policy one. Investments of 0.115 educational units can be financed for each level of productivity.

Policy one is less attractive because educational costs are now higher in countries with below-average education. Policy three, focussing on the students with low productivity, is superior to policy one. Policy two, focussing on preschool investments, is superior to policy three. In a homogeneous labour market, the effectiveness of educational investments aimed at reducing inequality increases, as shown in table 9 below. The human capital of the low-skilled increases out of proportion and reduces inequality. If additional investments are directed to the highskilled students, inequality will rise to 6.36 , moderately higher compared to 6.3 in regime one (see table 7).

Thus, alternative educational investment strategies have slightly different welfare consequences for the two regimes, depending on the degree of inequality aversion in a society (see table 10). Societies with a smaller inequality aversion $(\varepsilon=0)$ should shift more investments to younger children (policy two) while societies with a greater inequality aversion $(\varepsilon>0)$ should support mainly the low performing students (policy three, low skilled). Policy one is dominated by either the first variant of policy two or the first variant of policy three, irrespective of the inequality aversion. Policy one is furthermore dominated by the second variant of policy two. However, policy one is always better compared to the third variant of policy two and the second and third variant of policy three.

Table 9: Changes in inequality for policy regime two

\begin{tabular}{lccc}
\hline \hline \multicolumn{1}{c}{ Policy } & before Policy & after Policy & change \\
\hline Policy one, region & 6 & 5.52 & -0.48 \\
\hline Policy two, preschool & 6 & 5.44 & -0.56 \\
Policy two, primary school & 6 & 5.58 & -0.42 \\
Policy two, secondary school & 6 & 5.77 & -0.23 \\
\hline Policy three, low-skilled & 6 & 4.68 & -1.32 \\
Policy three, medium-skilled & 6 & 6.01 & +0.01 \\
Policy three, high-skilled & 6 & 6.36 & +0.36 \\
\hline \hline
\end{tabular}


Table 10: Welfare changes in regime one depending on inequality aversion $\varepsilon$

\begin{tabular}{lcccc}
\hline & $\varepsilon=0$ & $\varepsilon=0.5$ & $\varepsilon=1$ & $\varepsilon=1.5$ \\
\hline Policy one, region & $1.23 \%$ & $1.72 \%$ & $4.38 \%$ & $12.59 \%$ \\
\hline Policy two, preschool & $1.76 \%$ & $2.57 \%$ & $7.06 \%$ & $19.65 \%$ \\
Policy two, primary & $1.21 \%$ & $1.77 \%$ & $4.81 \%$ & $13.09 \%$ \\
Policy two, secondary & $0.43 \%$ & $0.66 \%$ & $1.89 \%$ & $5.09 \%$ \\
\hline Policy three, low-skilled & $1.65 \%$ & $3.45 \%$ & $13.58 \%$ & $44.37 \%$ \\
Policy three, medium-skilled & $0.91 \%$ & $0.90 \%$ & $0.39 \%$ & $-1.56 \%$ \\
Policy three, high-skilled & $0.60 \%$ & $0.18 \%$ & $-1.58 \%$ & $-4.96 \%$ \\
\hline \hline
\end{tabular}

\section{Conclusion}

The paper analyses alternative investment policies and their consequences for the evolution of human capital in Europe based on a model of age dependent skill formation where the life span depends on investments during childhood. A model is calibrated for a population living in 29 European countries in the year 2006. In the study Europe is either the sum of these individual countries or it is a hypothetical entity constructed from the 29 European countries. What makes the approach special is the analysis of the returns to education of alternative educational policies targeted at certain countries, ages or productivity levels for two counterfactual policy regimes, one regime assuming a single labour market and the other presupposing the actual state of diversity. In the model, investments for young individuals under the age of eighteen years are traced back to the family and teaching environment. In adulthood individuals optimize the amount of educational investments, given the overall amount of investments in the society.

The results demonstrate that optimal investment strategies, whether they are oriented towards age, regions or skill levels, crucially depend on the weights a society puts on equality. If equality is important enough more investment in Europe are needed for disadvantaged children during childhood. If the aim of equality is less important, additional investments need to be directed more generally to people of younger ages. Furthermore, it turns out that high levels of income inequality and a high skill level increases the optimal amount of investments, especially during younger adulthood.

The findings result from the idea of age depended skill formation with decreasing learning multiplier over time and decreasing marginal returns to investment in the skill production function. Further research is needed first for empirically assessing the skill multiplier from childhood in the different European countries with improved data. Second, additional research is needed to investigate the welfare consequences of public and private investment processes and alternative assumptions about their interdependencies. 


\section{References}

Amor, D. J. (2003), Maximizing Intelligence, New Brunswick, NJ: Transaction Publishers.

Atkinson, A. B. (1970), On the Measurement of Inequality, Journal of Economic Theory, 2 (3), 244-263.

Bergh, A. und G. Fink (2009), Higher Education, Elite Institutions and Inequality, European Economic Review, 53 (3), 376-384.

Blomeyer, D., K. Coneus, M. Laucht and F. Pfeiffer (2009), Initial Risk Matrix, Home Resources, Ability Development and Children's Achievement, Journal of the European Economic Association, 7 (2-3), 638-648.

Borgloh, S., B. U. Wigger, F. Heinemann, A. Kalb, F. Pfeiffer and K. Reuß (2011), Staatliche Anreize für private Bildungsinvestitionen - Effizienzanalyse, internationale Trends, Reformmöglichkeiten, Baden-Baden: Nomos.

Castelló-Climent, A. and R. Doménech (2008), Human Capital Inequality, Life Expectancy and Economic Growth, The Economic Journal, 118 (528), 653-677.

Caspi, A., B. W. Roberts and R. L. Shiner (2005), Personality Development: Stability and Change, Annual Review of Psychology, 56, 453-484.

Coneus, K., M. Laucht and K. Reuss (2011), The Role of Parental Investments for Cognitive and Noncognitive Skill Development - Evidence for the First 11 Years of Life, Economics and Human Biology (in press).

Cunha, F., J. J. Heckman, L. Lochner and D. V. Masterov (2006), Interpreting the Evidence on Life Cycle Skill Formation, in: E. A. Hanushek and F. Welsch (eds.), Handbook of the Eco-nomics of Education, vol. 1, Amsterdam: Elsevier Science \& Technology, 697-804.

Cunha, F. and J. J. Heckman (2007), The Technology of Skill Formation, The American Economic Review, 97 (2), 31-47.

Cunha, F. und J. J. Heckman (2009), The Economics and Psychology of Inequality and Human Development, Journal of the European Economic Association, 7 (23), 320-364.

De Boor, C. (1978), A Practical Guide to Splines, Berlin: Springer-Verlag.

Duckworth, A. L. and M. E. P. Seligman (2005), Self-Discipline Outdoes IQ in Predicting Aca-demic Performance, Psychological Science, 16 (12), 939-944.

European Commission (2009), Eurostat, http://epp.eurostat.ec.europa.eu/portal/page/portal/eurostat/home (retrieved 15.03.2011).

European Commission (2010), Eurostat, http://epp.eurostat.ec.europa.eu/portal/page/portal/eurostat/home (retrieved 15.03.2011). 
European Commission (2010), Europe 2020: A Strategy for Smart, Sustainable and Inclusive Growth, Brussels, http://eunec.vlor.be/detail_bestanden/doc014\%20Europe\%202020.pdf (retrieved 15.03.2011).

Frijters, P., T. J. Hatton, R. M. Martin, M. A. Shields (2010), Childhood Economic Conditions and Length of Life: Evidence from the UK Boyd Orr Cohort, 19372005, Journal of Health Economics, 29 (1), 39-47.

Hanushek E. A. and L. Wößmann (2008), The Role of Cognitive Skills in Economic Development, Journal of Economic Literature, 46 (3), 607-668.

Heckhausen, J. and H. Heckhausen (2008), Motivation and Action, Cambridge: Cambridge University Press.

Heckman, J. J. (2007), The Economics, Technology and Neuroscience of Human Capability Formation, Proceedings of the National Academy of Sciences, 104 (3), 132250-132255.

Heckman, J. J. and B. Jacobs (2009): Policies to Create and Destroy Human Capital in Europe, IZA Discussion Paper, No. 4680, Bonn.

Hunter, B., G. P White and G. Godbey (2006), What Does It Mean to Be Globally Competent, Journal of Studies in International Education, 10 (3), 267-285.

Johnson, W. R. and S. Turner (2009), Faculty without Students: Resource Allocation in Higher Education, Journal of Economic Perspectives, 23 (2), 169-189.

Lerner, J., A. Schoar and J. Wang (2008), Secrets of the Academy: The Drivers of University Endowment Success, Journal of Economic Perspectives, 22 (3), 207222.

OECD (2006), Education at Glance 2006, Paris.

OECD (2009), OECD.statExtracts, http://stats.oecd.org/Index.aspx (retrieved 15.03.2011).

OECD (2010), Education at Glance 2010, Paris.

Pfeiffer, F. und K. Reuß (2008), Age-Dependent Skill Formation and Returns to Education, Labour Economics, 15 (4), 631-646.

Richardson, D. and M. M. D'Ercole (2009), Doing Better for children: The First OECD Report on Child Well-Being, $3^{\text {rd }}$ OECD World Forum, 29.10.2009, http://www.oecd.org/dataoecd/47/50/44120958.pdf (retrieved 15.03.2011).

Sen, A. and J. Foster (1997) ${ }^{2}$ [1973], On Economic Inequality, Oxford: Clarendon Press.

Wößmann, L. (2008), How Equal Are Educational Opportunities? Family Background and Student Achievement in Europe and the United States, Zeitschrift für Betriebswirtschaft, 78 (1), 45-70. 